\title{
COVID-19 and legalized criminality: notes from the Arizona Borderlands, Part 2
}

\section{Linda Green ${ }^{1}$}

Published online: 29 August 2020

(C) Springer Nature B.V. 2020

\section{Impunity and the rule of law}

In a 2008 essay published in Dialectical Anthropology, "A Wink and a Nod: Notes from the Arizona Borderlands," I describe the inequities that pervade American jurisprudence in the borderlands of the American southwest. I contrast how the "rule of law" applies differentially to migrants who cross the border without official documents, in sham trials known as Operation Streamline, with the trial of a Border Patrol (BP) agent accused of second-degree murder. A 22-year-old Mexican man was shot by the agent at point blank range in the Sonoran Desert of Arizona. Both court proceedings were held simultaneously in Federal District Court in Tucson, AZ. For over a decade 50-70 shackled migrants appear daily before a federal judge in Streamline, plead guilty in unison to a felony charge of unlawful entry that is reduced to a federal misdemeanor conviction as part of a plea deal. ${ }^{1}$ Migrants are then sentenced to serve between 30 and 180 days, in mostly private detention centers here in AZ before their deportation. The length of the sentence depends on how many times they have previously been caught entering the USA without papers or picked up by Immigration and Customs Enforcement (ICE) in the Interior.

While the Border Patrol agent's first trial ended in a hung jury, even though the ballistic evidence was compelling ${ }^{2}$; the second trail exonerated him. The agent's defense was that he was afraid for his life. He claimed the migrant had a rock in hand to crack his skull, a fact which eyewitnesses disputed. Moreover, the BP agent is 6'4" and weighs 250 pounds, while the migrant was 5'3"and weighed 145 pounds.

Between 2003 and May 2018 Border Patrol agents have killed at least 97 people, including 28 US citizens and six children. Since 2010 at least eight of the victims were on the Mexican side of the border when they were killed. Yet, from 2007 to 2014 only a handful of BP agents

\footnotetext{
${ }^{1}$ These trials are currently suspended due to the COVIC pandemic.

${ }^{2}$ Although the BP agent at trial claimed he shot the migrant from 4 feet away, ballistics evidenced determined that the migrant was shot within a range of 3-12 inches and the bullet traveled down through the lungs, to his heart, and stomach, further concluding that he bled to death within $15 \mathrm{~min}$.
}

Linda Green

lbgreen@arizona.edu 
were disciplined for excessive use of force or had criminal changes brought against them. And even when charges have been brought against BP agents, they are almost never convicted.

Impunity prevails not only in the legal but also in the social sense, making a mockery of the American justice system as fair and unbiased. Within this matrix social impunity flourishes among members of the dominant society rendered through historical amnesia that generates a widespread indifference to the plight of "illegals." In the case of Central America and Mexico it includes the "forgetting" of ongoing complicity of US imperialism that creates conditions for economic exploitation and political repression to proliferate.

\section{Living in a state of fear}

In the ensuing 12 years, perhaps not surprisingly, much has changed in the borderlands, although mostly for the worst. Southern Arizona has been increasingly militarized. There has been an unprecedented build up in the Custom and Border Protection (CBP) forces with weaponry, agents, and infrastructure, including the ludicrous wall. Checkpoints abound under Border Patrol jurisdiction. CBP has the authority to operate within 100 miles from any US land or coastal border. This is not trivial, as 200 million people in the USA live within what the ACLU calls a "Constitution free zone." Warrantless stops based on "probable cause" are permitted in spite of the 4th Amendment. In 2010 the Arizona State Legislature passed the controversial SB 1070 law that gives local police the right to stop anyone who is "suspected" of being the US "illegally." The law unambiguously teaches brown-skin people to know their place whatever their documentation status. ${ }^{3}$ Although in 2012 The US Supreme Court struck down three of the four provisions of SB 1070, the fourth, 2B "papers on demand," was left standing. It remains in place in 2020.

\section{State-sponsored crimes}

In 1994 the Clinton Administration signed The North American Free Trade Agreement (NAFTA) with Mexico and Canada. The fallout from NAFTA was swift. In the first year after its passage over 1 million small farmers in Mexico lost their land. The number of migrants crossing the USMexico border surged as the US became a magnet for a cheap, exploitable, and "illegal" labor force without any protections as workers or even as human beings. At the same time the border was designated as a National Security risk that included both contraband and human smuggling. The infamous "prevention through deterrence" policy, however, was directly aimed at the predicted increase in "economic migrants" from Mexico and later the Central American countries of Guatemala, El Salvador, and Honduras, as the fallout from "free trade" took hold. The logic behind "prevention through deterrence" was purportedly to make the conditions for crossing the border so onerous - rather than the traditional routes near urban ports of entry - that migrants would not risk the dangers inherent in crossing the inhospitable Sonoran Desert in southern Arizona, the high mountains of California, or the most dangerous sections of the Rio Grande in

\footnotetext{
${ }^{3}$ Over a quarter-million US citizens in Arizona live with at least one family member who is undocumented. A total of 275,000 undocumented migrants in Arizona comprise about $28 \%$ of the immigrant population and $4 \%$ of the total state population in 2016. Prior to SB 1070 an estimated one-half million undocumented people lived in AZ. Many fled after its passage.
} 
Texas. The policy has failed spectacularly. Nonetheless, for over two decades and countless, avoidable deaths, it continues unabated.

The only thing you can hear in the desert at night are crickets and fear 100 square miles of desert crackling with fear .......as they (the migrants (sic) are like deer surrounded by lions. Chuck Bowden

Yet, not unexpectedly, the strategy turned the Sonoran Desert into a killing field on a militarized border. Some Border Patrol agents, reportedly work in concert with armed militias in search of "illegals." The US state knowingly created a space of death that punishes people least able to defend themselves. The official body count of more than 3,000 corpses or skeletal remains found in the $\mathrm{AZ}$ borderlands over the past two decades represents the tip of the iceberg, because these numbers count only corpses or skeletal remains recovered by accident not lost lives.

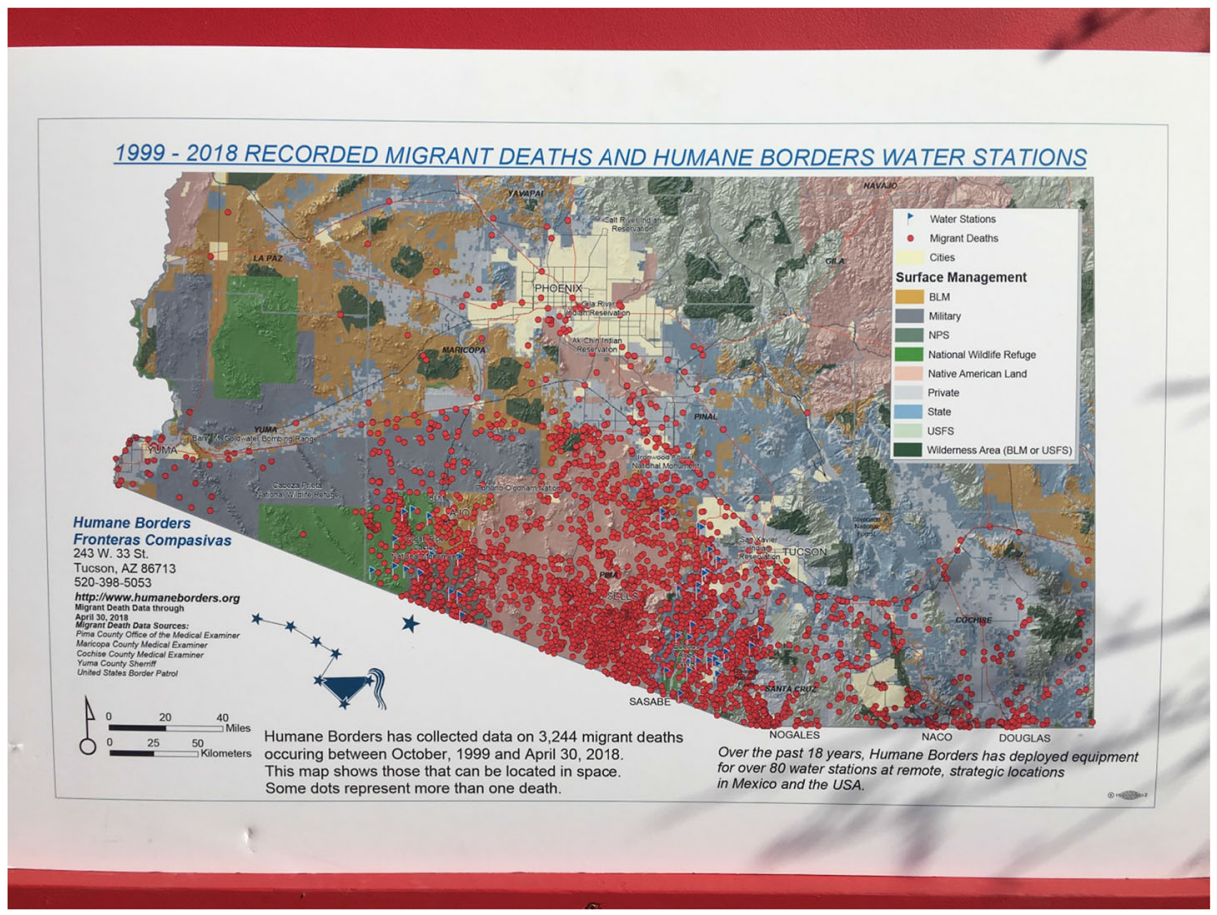

\section{Institutionalized corruption}

After 9/11 George W. Bush created the Department of Homeland Security, doubling the number of BP agents along the border, now around 20,000 with most (16,000+) stationed along the southern border. In the rush to fill the quota two problems emerged: (1) preemployment screening standards were lowered and (2) inadequate field training in the appropriate use of force. 
According to several outside evaluations of the agency the laxity in recruitment standards has led to increased levels of corruption and criminal activity within the BP ranks, including smuggling, money laundering, and conspiracy. In fact, some of the BP agents have known ties to Mexican cartels. The FBI has called corruption within the CBP ranks as one of the most serious sources of criminal activity along the border. By CBP's own admission approximately $80 \%$ of the lucrative drugs smuggled into the US along its southern border-heroin, cocaine, methamphetamine, and fentanyl - cross through ports of entry.

Secondly, there has been an ongoing lack funds for adequate field training in the appropriate use of force for a civilian law enforcement agency. Over the past 5 years, in particular, $\mathrm{CBP}$ has had serious problems fulfilling and retaining its agents. One strategy has been to recruit soldiers returning from the Iraq and Afghanistan war theatres. Veterans now make up about $30 \%$ of the workforce. Unlike in the military, where rules of engagement often take place within the context of combat, in the US borderlands the vast majority of the time BP agents are dealing with unarmed civilians who pose no serious threat. Without adequate training those distinctions in practice are often lost. Despite a budget in 2020 of almost \$19B, these two issues, which have been well known to CBP officials for years, have never been seriously addressed, although they have had significant consequences not only for the migrants who cross but also for residents of the borderlands.

It is increasingly dangerous to traverse Mexico and to cross the border into the US. The necessity of securing a coyote (guide) has become an imperative, and the price has risen accordingly. ${ }^{4}$ One of the far-reaching effects of US border policies and practices is that they have created a climate where multi-billion-dollar Mexican criminal enterprises of human and drug smuggling flourish.

Over the past decade the ICE detention system has grown by more than $45 \%$ and 9 out of 10 of the largest immigration detention centers are run by private, for-profit prison companies. Two of the largest, GEO Group and CoreCivic, between them contract for $62 \%$ of the detention beds for non-criminal confinement of the migrant population including those seeking asylum. In 2009 Congress passed legislation guaranteeing a minimum bed quota of 34,000 daily at $\$ 124$ per bed, filled or not. There is little oversite of these centers where confirmed reports of abuse and human rights violations, ranging from poor, inadequate food, medical care, and deplorable living conditions to sexual assault, rape, and unexplained deaths. By 2014 both corporations were expanded to include family detention facilities. Plunder unbound.

\section{"Deporter in Chief"}

Under the Obama Administration (2009-2016) deportations of undocumented migrants skyrocketed. With the removal of more than 2.5 million people on his watch, his deportation record surpassed that of all 20th century US presidents combined. The Administration claimed to be deporting those with criminal records, yet $2 / 3$ of those deported had no record or the charges were for minor, non-violent offenses. And those who had been convicted in Operation Streamline were counted as some of those criminal deportations.

\footnotetext{
${ }^{4}$ In 2019 it could cost as much as US\$8,000 from Mexico to the US border. People were often extorted along the way adding to the already exorbitant cost. If they or their family members are unable to pay, violence is used against them to extract the price, including rape, kidnapping, and murder.
} 
A "surge" the Department of Homeland Security (DHS) called it. By summer 2014 tens of thousands of women, children, and youth from Central America were streaming across the US-Mexico border seeking asylum. And the scenario has repeated itself over the last 5 years; a surge followed by a steady flow of refugees. Each time the US response has been more brutal than the last. During the Obama administration, for example, large numbers of asylum seekers were deported "to send a message." The implicit message: "no matter what your circumstances do not seek asylum in the United States." Jeh Johnson, head of Homeland Security under Obama, was more explicit, noting that the only way to cut down on the surge of migrants was "by demonstrating that asylum seekers wouldn't receive leniency." 5

Some of the asylum seekers never even reach the US-Mexico border as a result of an agreement between the US and Mexico in which Mexican authorities detain and deport record numbers of people in transit. According to Tucson-based investigative journalist, Todd Miller the US-Mexico border now extends to the Mexico-Guatemala corridor to the boundary between Guatemala and Honduras where BORTAC agents act as advisors to the Guatemalan military. Human rights violations by state authorities in all three countries involved have been well documented. Moreover, for those who do reach the border there have been serious accusations of abuse, rape, extortion, and robbery while in US Border Patrol custody, in the desert, at holding stations, and in detention. So, for the people seeking asylum the violence that sent them on this dangerous journey continues.

In its attempt to address the underlying cause of the humanitarian crisis Obama Administration in 2015 initiated The Alliance for Prosperity. The \$1 billion 5-year funding to Northern Triangle countries was designed to stem the tide of refugees that includes women, children, and unaccompanied youth. But the plan failed to address the reasons that underlie the poverty and violence that drives "surges." Rather its emphasis remained wedded to the litany of economic growth, infrastructure projects, foreign investment, and security initiatives in conjunction with Central American leaders. More than half the funds went towards security, military initiatives, and military training with little accountability especially with regard to human rights violations. The Alliance for Progress echoes an earlier initiative, the 1960 s Alliance for Progress. ${ }^{6}$

\section{Why do they come?}

The neo-liberal trade agreements and moribund Peace Accords that proliferated across Mexico and Central America in the 1990s left few possibilities for most semi-subsistence peasants, alongside their urban counterparts, to create a future for themselves and their families. Neoliberal migration became one of the last options for procuring a future, what Jason Chacon and Mike Davis poignantly describe as "informal survival." Today the situation for many rural families is more precarious than it was a quarter century ago.

Impunity, too, has permeated the social fabric in the rural countryside. At the community level some men who actively participated in the reign of state terror now hold positions of power in local institutions. Fear continues to be an effective mechanism of social control in everyday life, and where the calculations of whom to trust can lead to lethal consequences as

\footnotetext{
${ }^{5}$ Harlin, Chico 2016. Inside the Administration's \$1Billion Deal to Detain Central American Asylum Seekers. Washington Post 14 August.

${ }^{6}$ In March 2019 Trump suspended most aid to the Northern Triangle countries (Guatemala, El Salvador and Guatemala).
} 
guns, gangs, and criminal enterprises rule. As James Dunkerley ${ }^{7}$ argues the term "economic refugees" may hide a much more complicated reality where the "... 'push factor' is far more complex and nastier than simple privation."

Now international criminal cartels, drug cultivation, and trafficking corridors abound. Local gangs with ties to larger networks of criminality operate throughout the region with a flourish. As a result, ordinary people live under the threat of gang activities that include kidnapping, sexual assault, and extortion, one of its principal sources of income. Refusal to pay is considered an affront to gang authority that is in turn met with threats, violence, and even death. In 2014, $20 \%$ of all murders in Guatemala were due to failure to pay extortions. According to a recent study by Doctors Without Borders (2020) 2/3 of the people from the Northern Triangle countries seeking refuge have experienced the murder, disappearance, or kidnapping of a relative before their departure. Moreover, there has been a substantial increase in violent crimes exacerbated by the proliferation of firearms imported from the US since the ending of the counterinsurgency wars. Over the past decade the three Northern Triangle countries have consistently been ranked in the top five countries in the world not at war for homicide and femicide.

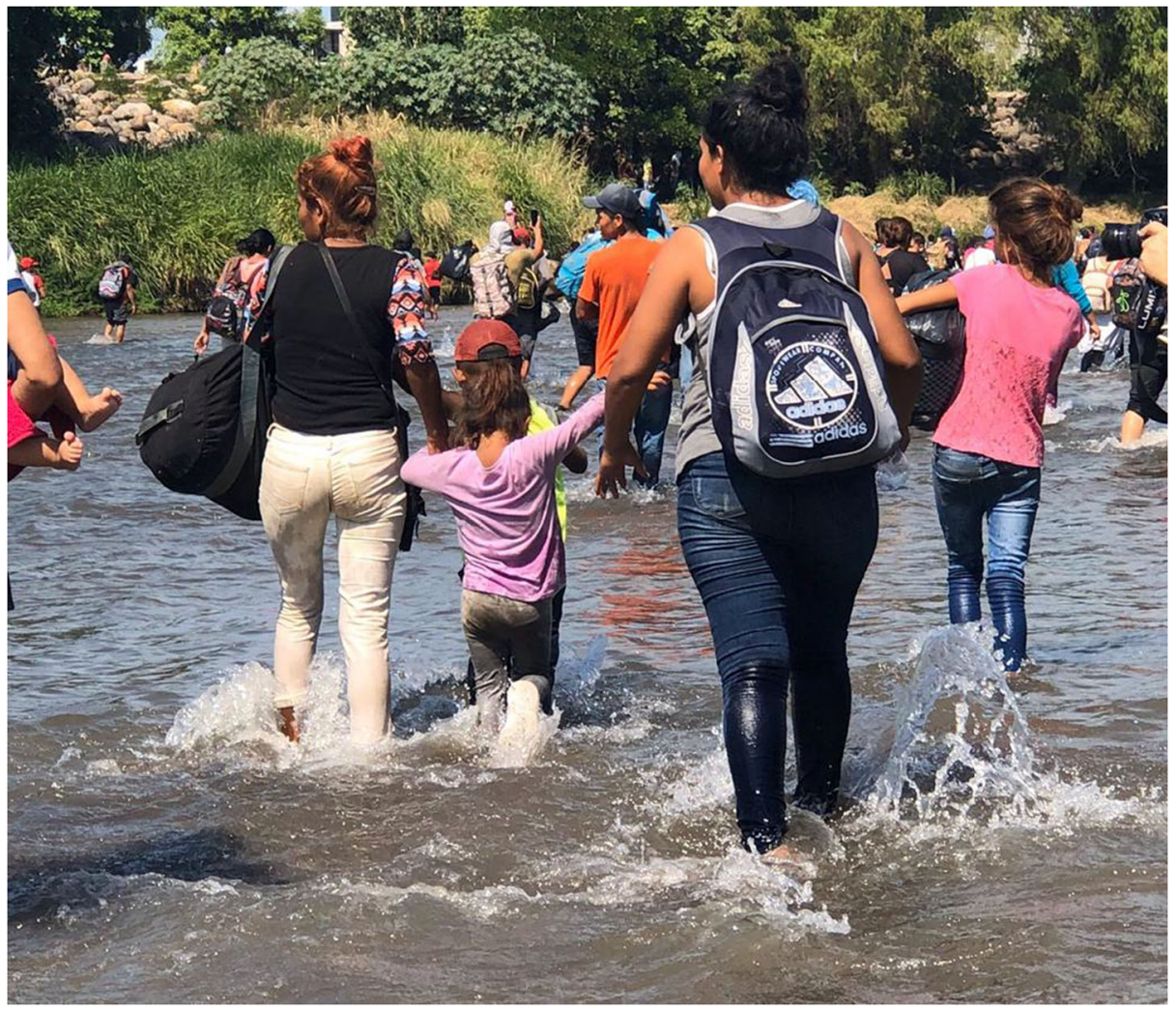

Photo Caption: Migrant caravan crossing the Suchiate River between Guatemala and Mexico. 2018 Photo courtesy of Luis Argueta

\footnotetext{
${ }^{7}$ Dunkerley, James (1994:46) The Pacification of Central America. London: Verso
} 
Unresolved land conflicts stemming from displacement and dispossession during the wars exacerbated the fractures and divisions among and between community members. Weak, ineffective, or non-existent national judicial institutions and well-founded lack of trust in the mostly corrupt national police render impunity widespread. International resource extraction has increased insecurity and violence in rural communities across the region. For example, in Guatemala although the government is a signatory to the Convention 169 on the Rights of Indigenous and Tribal Peoples (International Labor Organization), it has nonetheless granted transnational corporations permits to develop mines, hydroelectric, and oil projects on indigenous lands without the express permission of the affected indigenous communities. In fact, the permits have been granted even after local referendums have overwhelming rejected the projects.

In 2018 Guatemala had the highest murder rate per capita of land defenders in the world. Honduras, too, has been the site of extensive violence against land and water protectors. The climate crisis is most evident in this region where severe draughts have disrupted the subsistence agricultural cycle, leaving large swaths of the population hungry and malnourished, over $1 / 2$ of the regional population lives without sufficient food. About $80 \%$ of the corn crop, the stable food, was lost in the 2019 growing season due to drought. Many people are going hungry. In 2019, according to an Oxfam report, health official registered more than 15,000 case of acute malnutrition in children under 5 years old in Guatemala. This was an increase of almost 325\% from 2018. Guatemala also has the 6th highest chronic malnutrition or anywhere in the world.

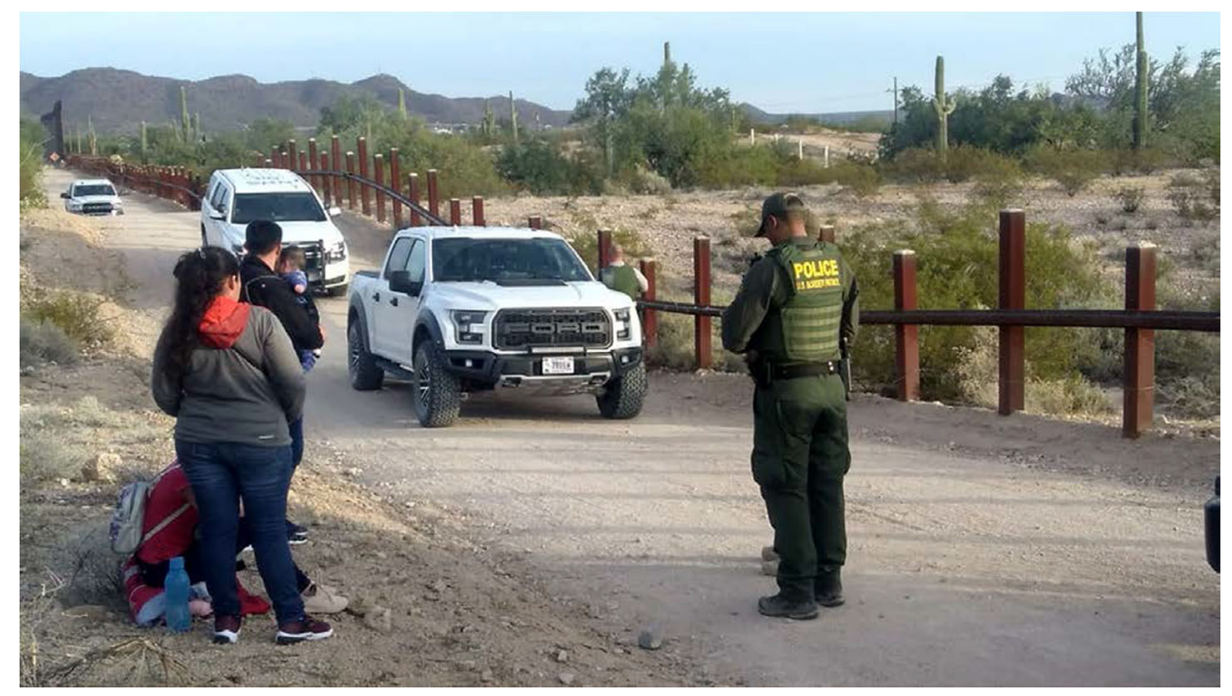

BP arrest.

\section{Deliberate indifference}

Deliberate Indifference is the conscious or reckless disregard of the consequences of one's acts or omissions ...for the very purpose of causing harm or with knowledge that harm will result.

Trump inherited the most sophisticated deportation machine in US history. He has not really added any new laws per se, but rather has intensified what was already in place, albeit more viciously and cruelly. In particular, Trump has gone after asylum seekers with a vengeance. 
One of his initial gambits was a "zero tolerance" policy that separated children from their parents at the border. The policy officially adopted between April and June 2018 placed children in squalid cages under the auspices of the Department of Health and Human Services (DHHS), the Office of Refugee Resettlement (ORR), while their incarcerated parents awaited adjudication of their asylum claims. No provisions were made to adequately and judiciously reunite the children with their parents. No one knows for sure how many families were separated nor how many have been successfully reunited. ${ }^{8}$ This is the American version of Central American disappearances.

Beginning in 2018 large numbers of people began arriving at the US-Mexico border asking for asylum. The Trump administration's response to the humanitarian crisis: a show of force against caravans of mostly women, children, and unaccompanied youth from Northern Triangle countries seeking protection from harm, reached its public apogee between November 2018 and January 2019. BP agents repeatedly fired tear gas at asylum seekers who lined the sidewalks on the Mexican side of San Diego-Tijuana border. CBP claimed it necessary to do so in response to rock throwing and attempts to cross the border "illegally."

But the real provocation has been a set of policies that the Trump administration instituted that made seeking asylum at the US-Mexico border a near impossible task. I outline three of the most disingenuous policies, ones that perhaps border on the criminal.

+Metering: (April 2018) to ask for asylum the Border Patrol agents instructed migrants that they must do so only at ports of entry. This is a blatant lie. Anyone has the right to seek refuge and protection no matter where and how they enter the country and that right is available for up to a year from entry. Metering 9 has meant that the process is not only cumbersome but dangerous. I spoke with families living in the sidewalks of Nogales Sonora in fall 2019 who had been waiting weeks and in some cases months for their number to be called so they begin the petition process for asylum.

+ Migrant Protection Protocols (aka Remain in Mexico) (December 2018): Once an asylum seeker has started the petition process they are given a notice to appear in immigration court and then sent back to Mexico to wait, rather than being allowed entry into the USA. If someone expresses fear of returning to Mexico then they are detained in US custody to wait for their "credible fear interview" with an asylum official. If they are traveling with their children it means they will be separated from each other.

The entire program is flawed (and perhaps illegal) in too many ways to enumerate here. Suffice it to say that if someone misses their court date in the US, while waiting in Mexico, they are ineligible for asylum. But what is known is that BP agents often give the wrong date for the court appearance, or two members of the same family must appear is two different places at the same time. For example, some family members waiting in Nogales, Sonora, might have to appear in El Paso, TX, while on the same day another member must be in San Diego, CA. This strategy creates unnecessary confusion and expense, even as their lives are at stake. Moreover, these border cities on the Mexico side are some of the most dangerous in the world. The US State Department classifies, for example, the Mexican border state of Tamaulipas at same level of danger as Syria, Iraq, and Afghanistan. There have been multiple documented case of rape, kidnapping, extortion, and assault against people waiting.

\footnotetext{
${ }^{8}$ Although the official policy statement was that family separation only took place between April and June, in fact, there were "trial" separations happening in the Tucson sector in 2017 and even today in 2020 in some instances, separations continue. Moreover, in 2019 legal documents show that DHHS and DHS officials knew that the physical conditions in child detention centers were woefully inadequate and that separation caused trauma with its predictable long-term effects.

${ }^{9} \mathrm{CBP}$ at most ports of entry were only processing 10 migrants petitioning for asylum per day.
} 
+Asylum Transit Ban is perhaps the most blatantly absurd of all. Beginning in July 2019 any individual seeking asylum at the southern border who passes through another country enroute must apply for asylum in that country. So, if you are fleeing the violence in Honduras you are obliged to apply for asylum in Guatemala, even as Guatemalans are fleeing the violence there.

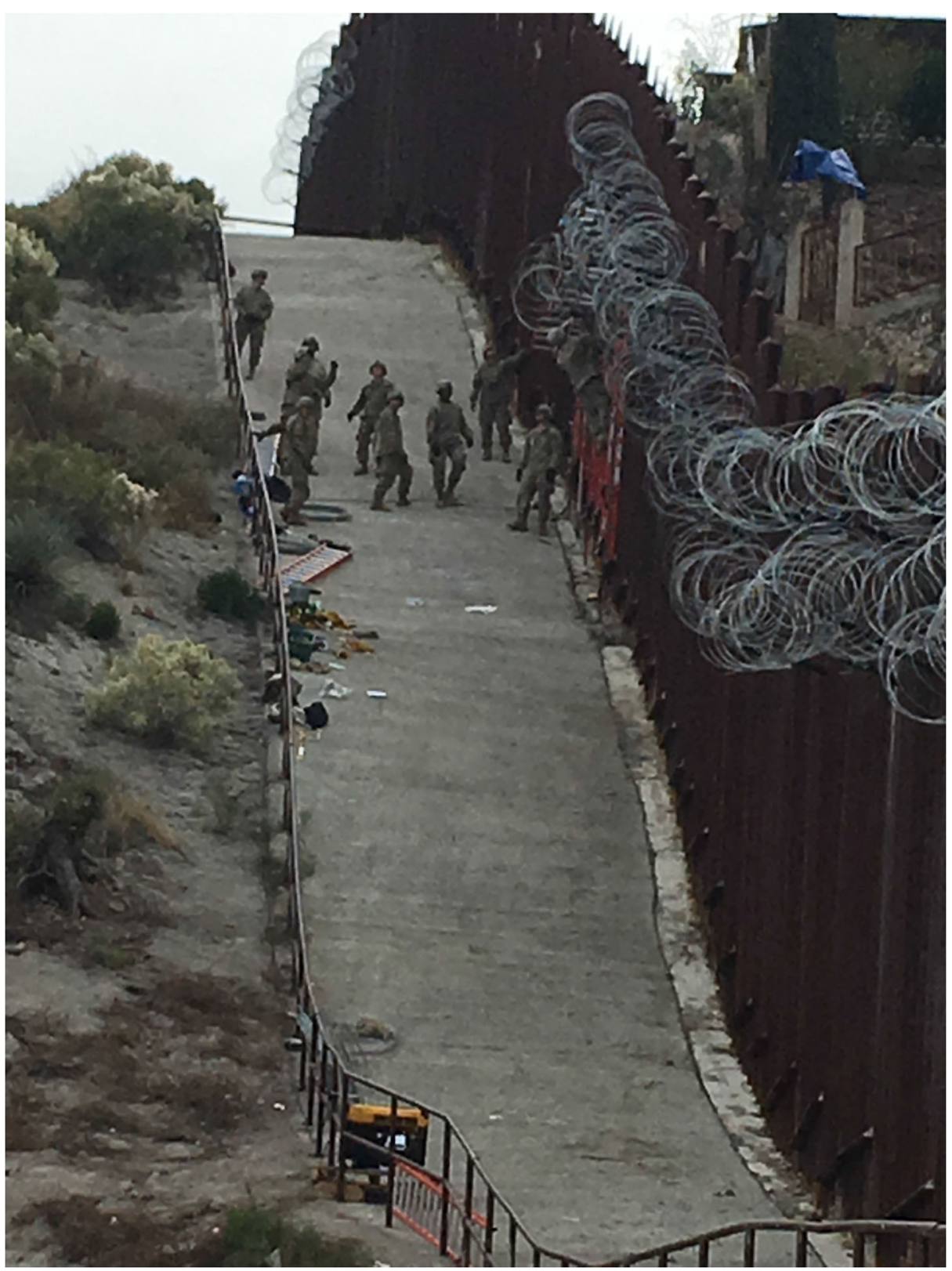

Photo Caption: US Military deployed from Ft. Bliss, TX, to the border at Nogales, AZ, to fortify the wall with concertina wire. December 2018 
In 2018 Trump ordered the deployment of 5,000 active duty military, who joined National Guard troops as well as the Border Patrol to stop the advance of the "hordes." In that some year Trump changed the rules of engagement for US troops and the Border Patrol to include anyone throwing rocks. "We will consider it a rifle." According to Trump "they want to throw rocks at our military, our military fights back. I told them to consider it a rifle." I guess Trump did not realize that BP has long been doing just that. Between 2010 and 2014 of the 24 cases where Border Patrol agents shot and killed people at the border, agents offered rock throwing as justification.

The 2012 case of a 16-year-old of Jose Antonio Elena Rodriquez is noteworthy in that regard. He was shot in the back ten times in Nogales, Sonora, by a Border Patrol agent who fired through the fence while standing in Nogales, AZ. The agent, Lonnie Swartz, claimed Elena Rodriquez was throwing rocks and he was afraid for his life. One hitch stands out among many. The BP agent was literally standing on higher ground, behind the wall (18 ft), which is perched on a mound approximately 20 feet high. According to eyewitnesses the agent fired his weapon repeatedly, reloaded, and fired again. In 2018 BP Agent Swartz was found not guilty on second-degree murder charges. At a second trial he was again acquitted this time on the lesser charge of involuntary manslaughter. Impunity reigns.

\section{COVID and crimes against humanity}

Crimes against humanity are not isolated or sporadic events but are part either of a government policy or a wide practice of atrocities tolerated or condoned that can be committed during peace or war. Crimes against humanity have three key components: a physical element-that includes inhumane acts, a contextual element: "when committed as part of a widespread or systematic attack directed against any civilian population," and a mental element "with knowledge of the attack." According to Article 7(2) of the Rome Statute the plan or policy does not need to be explicitly stipulated or formally adopted and can therefore be inferred from the totality of the circumstances.

Donald Trump declared the pandemic a national emergency on March 13, 2020. On the afternoon of the same day I was testifying as an expert witness in an asylum hearing in a courtroom housed in a private detention center outside Phoenix. Absurdly, mid-way through the court proceedings a guard rush in with paper masks saying that everyone who was not a government employee had to wear one. Six of the seven of us crowded around the $(4 \times 6 \mathrm{ft})$ table were ordered to wear a mask. The DHS attorney who sat next to me was not given one nor the judge. No one I asked could account for its logic.

By the end of March Trump issued an order to immediately deny entry to noncitizens arriving at the border and with no possibility of requesting sanctuary. In the following 6 weeks CBP denied entry to some 20,000 people, including 400 undocumented children, the vast majority from Mexico and Central America. Then Trump also invoked an obscure public health law to shut down asylum altogether.

Moreover, ICE continues to hold tens of thousands of asylum seekers and migrants in detention centers with their notoriously overcrowded, dangerous circumstances, made all the more so by COVID-19 that thrives under such conditions. Even given the paucity of public data available it is estimated that well over $20 \%$ of the asylum seekers and migrants while held in detention are positive for the virus: no hygiene, no protective gear, no social distancing. 
Yet at the same time that borders were shutting down and public health officials advised restriction on movement; ICE chartered more than 350 flights to Latin American and Caribbean countries between February and June 2020. The US has failed to consistently test people before their departure. And even when they were pressured to do so, ICE officials did little more than a temperature check and asking if someone had symptoms. Rather than releasing people to their families in the US where they could remain until the pandemic receded, the Trump administration continued to deport people who were infected with the virus while in custody. It also inexplicably moved people from one detention facility to another across the country. The ICE strategy seems to be detain, infect, and deport. The vast number of flights went to the Northern Triangle countries, which are now surging in COVID cases. The antiquated public health system in Guatemala, for example, has collapsed under the weight of soaring infections and deaths. Many of the deportees and those dying in Guatemala are indigenous.

The Trump administration policies certainly rise to the level "crimes against humanity" in the moral sense and may well fit within its legal parameters.

\section{Postscript: humanitarian aid as a state crime}

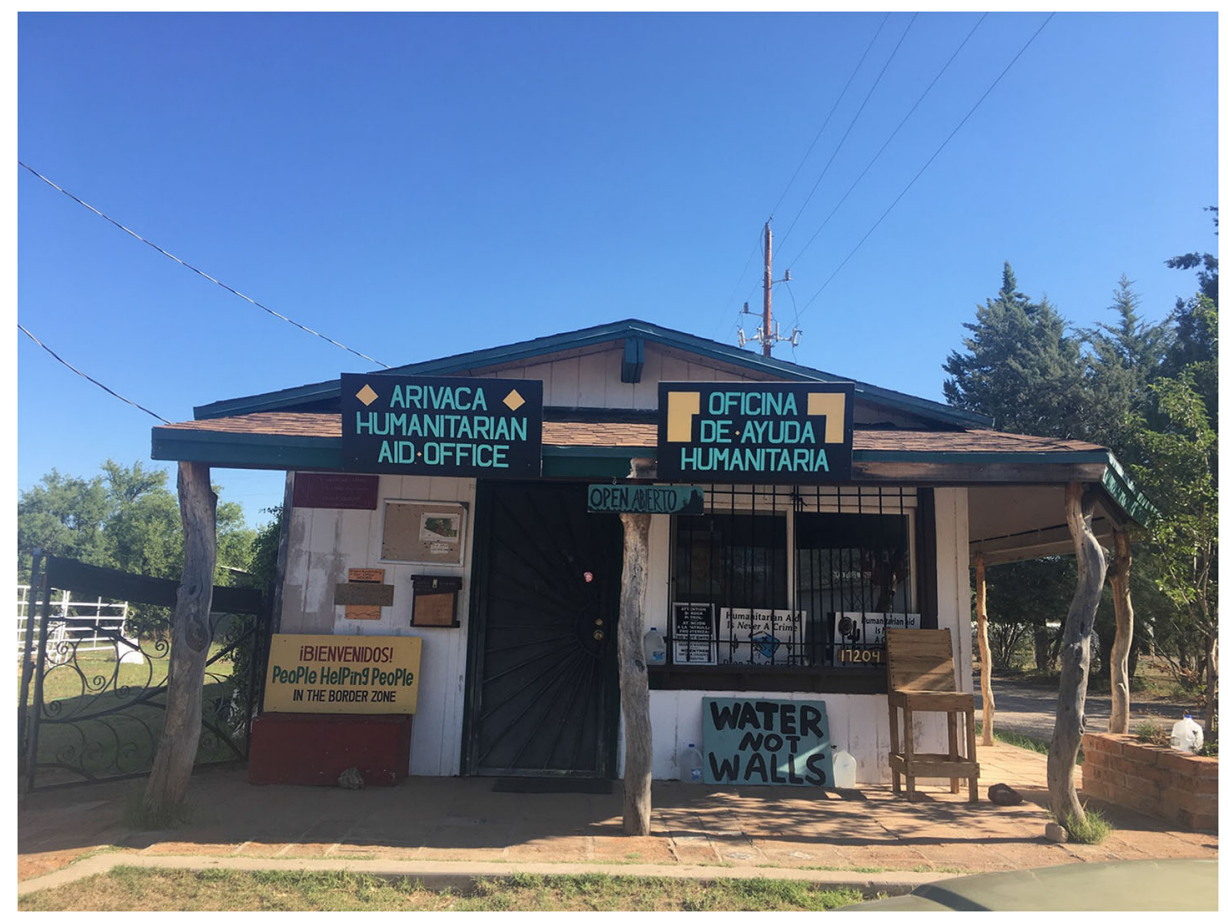

Photo caption: The central humanitarian aid office in the town of Arivaca, population 700. The Byrd camp is located in a valley southwest of the town 
As I write this essay No More Deaths/No Mas Muertos, the Tucson-based humanitarian aid group that has been working in the borderlands of Arizona since 2004 was raided by Border Patrol on two successive nights-30 and 31 July. Border Patrol agents entered the Byrd Camp in Arivaca, located about 10 miles from the border, where volunteers assist migrants who need medical aid. Severe dehydration and incapacitating blisters on the soles of one's feet are common when walking in the $110 \mathrm{~F}+$ heat of the Sonoran Desert in the summer. Despite not having a warrant that first night Border Patrol agents entered onto private property and detained a woman who they suspected of being in the country "illegally." The following night at dusk over 30 Border Patrol returned, this time with a warrant in hand, buttressed by two helicopters, armored vehicles, and vans both marked and unmarked. Reportedly, agents from BORTAC the now infamous Border Patrol tactical (counterinsurgency) squad were among those who entered the camp that night. About $30+$ migrants in need of some form of assistance were arrested. Their crime: crossing the border without papers. BP also confiscated volunteer cell phones and camp records. The volunteers remain steadfast and despite the raids have kept the camp operating.

State violence directed against humanitarian workers in general and No More Deaths in particular is nothing new. Since 2006 when Border Patrol arrested 2 No More Death's volunteers for transporting migrants in need of medical attention to 2019 trial of Dr. Scott Warren on the felony charge of harboring two migrants and now the recent incident of Border Patrol raiding the Byrd Camp, its actions suggest that Border Patrol and thus the US State do indeed think that humanitarian aid is a crime.

Over the years colleagues have asked how I like living in Arizona. I have often rather glibly responded: "Where else can you live the future?" As Trump continues to wall us in both literally and figuratively, our future is now. 


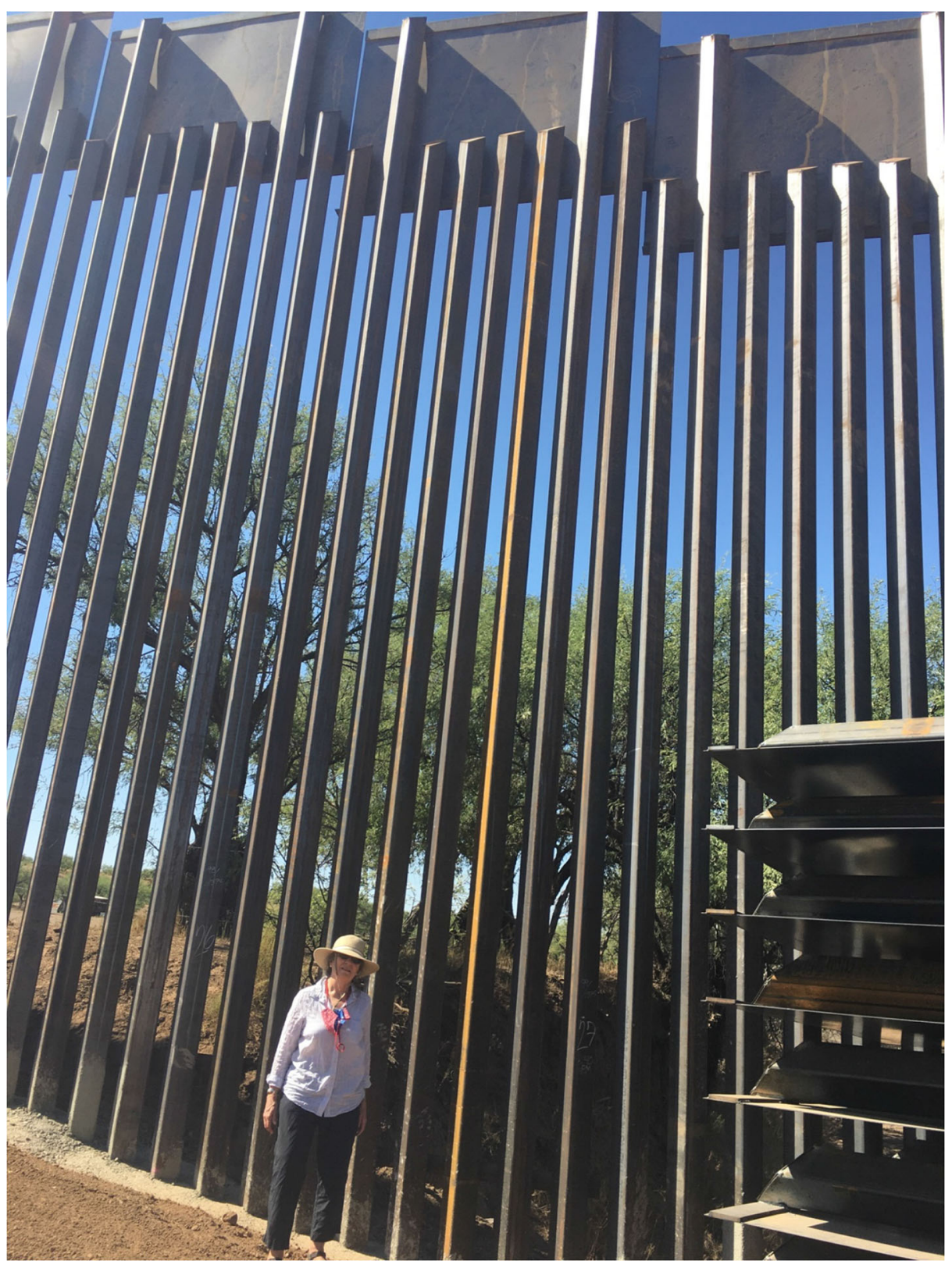

Caption: Trump's $30 \mathrm{ft}$ high border wall near Sasabee AZ. Estimates are that the wall cost on average \$20 million per mile. The environmental devastation to the border region is incalculable

Publisher's note Springer Nature remains neutral with regard to jurisdictional claims in published maps and institutional affiliations. 